cemoti $\begin{aligned} & \text { Cahiers d'études sur la Méditerranée } \\ & \text { orientale et le monde turco-iranien }\end{aligned}$

$20 \mid 1995$

Médias d'Iran et d'Asie centrale

\title{
L'Afghanistan d'une guerre à l'autre : évolutions internes et dynamiques régionales
}

Alessandro MONSUTTI

\section{OpenEdition}

\section{Journals}

Édition électronique

URL : http://journals.openedition.org/cemoti/194

DOI : $10.4000 /$ cemoti. 194

ISSN : $1777-5396$

Éditeur

AFEMOTI

\section{Édition imprimée}

Date de publication : 1 juin 1995

Pagination :

335-351

ISSN : 0764-9878

Référence électronique

Alessandro MONSUTTI, «L'Afghanistan d'une guerre à l'autre : évolutions internes et dynamiques régionales ", Cahiers d'études sur la Méditerranée orientale et le monde turco-iranien [En ligne], 20 | 1995, mis en ligne le 30 mars 2004, consulté le 08 septembre 2020. URL : http://journals.openedition.org/ cemoti/194; DOI : https://doi.org/10.4000/cemoti.194

Ce document a été généré automatiquement le 8 septembre 2020

Tous droits réservés 


\title{
L'Afghanistan d'une guerre à l'autre : évolutions internes et dynamiques régionales
}

\author{
Alessandro MONSUTTI
}

\section{RÉSUMÉS}

Après le départ des troupes soviétiques en 1989 puis l'effondrement de l'URSS et la fin de la guerre froide, l'opinion publique s'est désintéressée du sort de l'Afghanistan, dont la situation interne apparaissait totalement inintelligible. Pourtant, l'Afghanistan, qui a récemment fait parler de lui dans les médias par l'irruption soudaine d'un nouvel acteur sur la scène politicomilitaire, les tâlebân les étudiants des écoles religieuses supérieures, reste au cœur d'enjeux politiques et économiques complexes. 